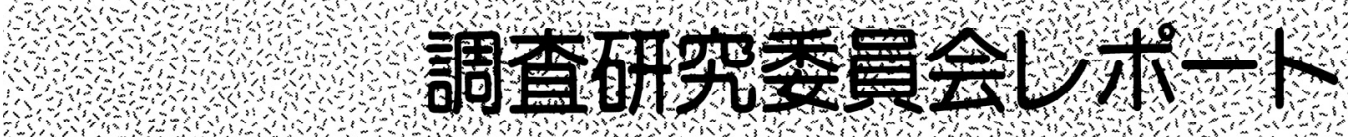

電力・エネルギー部門技術委員会・調查専門委員会の活動の内容・状況を報告する。

\title{
先進放射線利用技術調査専門委員会
}

\section{1. 設立趣旨}

放射線は，高い透過性・高指向性・線種／エネルギーに よる物質相互作用の差異を利用した非破壊検査や各種物性 測定等に，又は，高エネルギー密度・イオン化能力等によ る医療診断・治療や産業応用等に応用されており, 理工学・ 医学・薬学・環境・宇宙など様々な分野で広く利用されて いる。さらにこれらの特性を向上させ，より広い分野へ応 用す心゙く種々の努力がなされており，新規放射線発生手法 や，コンベンショナルではあるが取扱いの容易さを考慮し たコンパクトな発生装置の開発等，発生源としての開発が 強力に押し進められている。またこれら新規発生源に対応 した新しい検出器の開発も進められており, 最終的に発生 計測技術を組み合わせた利用技術として放射線応用システ ムの開発も進められつつある。本専門委員会は, 次世代に 普及が進むとされる各種量子ビームの相補利用に加え, 放 射性同位体を含む同位体科学の利用・計測技術の開発状況 を基礎から応用まで幅広い範囲で研究調查を行い, 現状の 課題について整理検討するとともに，利用応用に関わる新 たなニーズの調査も実施し, 今後のこの分野の技術動向に ついて展望することを目的とする。

\section{2. 調査研究活動}

2008 年 8 月より，執筆現在（2009 年 8 月）までに，調 査専門委員会を 5 回開催し，放射線利用技術について，第 一線の研究者よりご講演頂いた。また，2008 年 9 月に原子 力研究会を開催し， 2009 年 9 月にも開催が決定している。 さらに, 2009 年 3 月には原子カシンポジウムの開催に協力 した。これらの活動内容を，表 1 に示す。

表 1 調査研究活動の記録

\begin{tabular}{|c|c|}
\hline \multicolumn{2}{|l|}{ 第 1 回調査専門委員会 } \\
\hline 2008 年 8 月 25 日 於 & 電気学会本部 \\
\hline 豊川弘之（産総研） & $\begin{array}{c}\text { 高透過性光子ビームによる非破壊検査技術 } \\
\end{array}$ \\
\hline 木野村淳（産総研） & $\begin{array}{l}\mathrm{MeV} \text { イオンビーム及び低速陽電子ビームに } \\
\text { よる材料分析 }\end{array}$ \\
\hline \multicolumn{2}{|l|}{ 原子力研究会 } \\
\hline \multicolumn{2}{|c|}{2008 年 9 月 11 日 於 早稲田大学 } \\
\hline 海野泰裕（産総研） & 放射能標準 \\
\hline 宮入陽介（東大） & AMS による極微量同位体分析 \\
\hline 浮辺雅宏（産総研） & アレイ型超伝導トンネル接合検出器の製作 \\
\hline 伊豫本直子（東大） & $\begin{array}{l}\text { 超伝導転移端検出器による高エネルギー分解 } \\
\text { 能スペクトロスコピー }\end{array}$ \\
\hline 涉谷憲悟（放医研） & $\begin{array}{l}\text { "OpenPET"に向けたピクセルシンチレーシ } \\
\text { ヨン検出器の開発 }\end{array}$ \\
\hline \multicolumn{2}{|l|}{ 第 2 回調査専門委員会 } \\
\hline 2008 年 11 月 20 日 於 & 電気学会本部 \\
\hline
\end{tabular}

\begin{tabular}{|c|c|}
\hline $\begin{array}{l}\text { 弘中陽一郎（阪大） } \\
\text { 牧野俊一郎（東芝） }\end{array}$ & $\begin{array}{l}\text { 超高圧状態の同期 X線診断 } \\
\mathrm{He}-3 \text { 位置検出器を用いた測定システムの高 } \\
\text { 計数率化 }\end{array}$ \\
\hline \multicolumn{2}{|l|}{ 第 3 回調査専門委員会 } \\
\hline $\begin{array}{l}\text { 野村貴美（東大） } \\
\text { 榎本秀一（岡山大） }\end{array}$ & $\begin{array}{l}\text { 火星探査から先端材料分析のための } \gamma \text { 線核共 } \\
\text { 鳴分光法 } \\
\text { 生体内金属の動きを捉える : マルチトレーサ } \\
\text { 一法と複数分子同時イメージング } \\
\end{array}$ \\
\hline \multicolumn{2}{|l|}{$\begin{array}{l}\text { 原子力シンポジウム } \\
2009 \text { 年 } 3 \text { 月 } 19 \text { 日 於 }\end{array}$} \\
\hline $\begin{array}{l}\text { 長谷川智之（北里大学） } \\
\text { 金ウンジュ (放医研) } \\
\end{array}$ & $\begin{array}{l}\text { 治療用粒子線場でのグラファイトカロリメー } \\
\text { タによる絶対線量評価 } \\
\mathrm{PET} \text { 装置評価法と新規標準線源 } \\
\text { 緊急被ばくによおける放射線計測及び線量評価 }\end{array}$ \\
\hline \multicolumn{2}{|l|}{$\begin{array}{l}\text { 第 } 4 \text { 回調査専門委員会 } \\
2009 \text { 年 } 5 \text { 月 } 25 \text { 日 於 }\end{array}$} \\
\hline $\begin{array}{l}\text { 明連広昭（埼玉大） } \\
\text { 俵裕子（高エネ研） }\end{array}$ & $\begin{array}{l}\text { 超伝導素子を用いた大面積放射線検出器 } \\
\text { PADLES を用いた低地球軌道での宇宙放射 } \\
\text { 線計測 }\end{array}$ \\
\hline \multicolumn{2}{|c|}{ 第 5 回調査専門委員会 } \\
\hline $\begin{array}{l}\text { 前川立行（東芝） } \\
\text { 日塔光一（東芝） }\end{array}$ & $\begin{array}{l}\alpha \text { 放射能測定のための電離イオン式計測技術 } \\
\text { カラーI.I. }{ }^{\mathrm{TM}} \text { で広がる新しい検査技術 }\end{array}$ \\
\hline \multicolumn{2}{|l|}{ 原子力研究会 } \\
\hline $\begin{array}{l}\text { 福村利光（放医研） } \\
\text { 小林紘一（パレオ・ラボ） } \\
\text { 井頭政之（東工大） } \\
\text { 久保敏幸（理研） } \\
\text { 辻本和文（原子力機構） }\end{array}$ & $\begin{array}{l}\text { 核医学診断用核種の製造 } \\
\text { 年代測定 } \\
\text { 核データ計測 } \\
\text { 新同位元素の生成と発見 } \\
\text { 加速器駆動核変換システム }\end{array}$ \\
\hline
\end{tabular}

\section{3. 今後の予定}

先進放射線利用技術調査専門委員会の設置期限である 2010 年 6 月まで, 調査専門委員会を定期的に開催すると共 に, 2010 年 3 月に予定される原子カシンポジウムの開催に 協力する。先進放射線利用技術調查専門委員会における調 查内容は 2010 年度中に電気学会技術報告として出版され る予定となっている。

$$
\text { 幹事 佐藤泰・幹事補 藤田薰 }
$$

\footnotetext{
委 員 長桧野良穂 (産総研)

委 員 長 桧野良穂 (産総研)
委員 井口哲夫 名大), 石井慶造 (東北大) 伊藤敏明（東芝），神野郁夫（京大）

榮 武二（筑波大），坂佐井馨（原子力機構） 鈴木 功 (産総研), 高橋幸郎（埼玉大） 高橋浩之（東大），田所孝広（日立） 俵 裕子 (高エネ研), 取越正己(放医研) 中井光男（大阪大)，持木幸一 (都市大) 山田崇裕（RI 協会）

幹 事 佐藤 泰 (産総研)

幹 事 補藤田 薫 (原子力機構)
}

委員会構成メンバ 